\title{
APPLICATION OF INORGANIC FERTILIZER AND BIO-FERTILIZER ON CHLOROPHYLL CONTENT, PH, AND LEAVES NUMBER OF PAK CHOI (BRASSICA RAPA L.) IN HYDROPONICS
}

\author{
${ }^{\text {* Mieke Rochimi Setiawati }}{ }^{1}$, Haifa Fauziyyah Aini ${ }^{2}$, Pudjawati Suryatmana ${ }^{1}$ \\ and Reginawanti Hindersah ${ }^{1}$ \\ ${ }^{1}$ Soil Science Department, Agriculture Faculty of Universitas Padjadjaran, Indonesia. \\ Jl. Raya Bandung Sumedang Km 21 Jatinangor Kab. Sumedang 45363, Indonesia \\ ${ }^{2}$ Undergraduate student, Soil Science Department, Agriculture Faculty of \\ Universitas Padjadjaran, Indonesia. \\ Jl. Raya Bandung Sumedang Km 21 Jatinangor Kab. Sumedang 45363, Indonesia.
}

http://doi.org/10.35410/IJAEB.2019.4423

\begin{abstract}
Nutrient Film Technique (NFT) hydroponic systems is one of hydroponics types which utilizes water to supply the plant's nutrition needs and is circulated to plant's root through thin water. Hydroponic systems depends on inorganic fertilizer as nutrient solution. Utilization of biofertilizer is expected to reduce the inorganic fertilizer use applied in hydroponic systems. The aims of this experiment were to find the best dose combination of inorganic fertilizer and biofertilizer application toward chlorophyll content, $\mathrm{pH}$, and number of pak choi's leaves in NFT hydroponic systems. This experiment was conducted in Soil Biology Laboratory Faculty of Agriculture Universitas Padjadjaran, from November 2018 until April 2019. Experiment was arranged in Randomized Block Design (RBD) consisting of four treatments combination of Nitrogen Fertilizer (NF) in ammonium nitrate solution $(70 \mathrm{mg} / 2 \mathrm{~L})$ with $150 \mathrm{~mL}, 100 \mathrm{~mL}, 50$ $\mathrm{mL}$, and $25 \mathrm{~mL}$ doses combined with Bio-fertilizer (BF) with $0 \mathrm{~mL}, 75 \mathrm{~mL}, 125 \mathrm{~mL}$, and 150 $\mathrm{mL}$ doses. The result showed that combination of inorganic fertilizer and bio-fertilizer could increase the number of pak choi's leaves, however it shows the same effect on the chlorophyll content and $\mathrm{pH}$ compared to other treatments. The combination of $25 \mathrm{~mL}$ ammonium nitrate fertilizer dose and $150 \mathrm{~mL}$ bio-fertilizer was able to reduce the recommended dosage of ammonium nitrate by $83.33 \%$.
\end{abstract}

Keywords: Nutrient Film Technique, hydroponics, Bio-fertilizer, Pak choi.

\section{INTRODUCTION}

Hydroponics, which is also known as soilless culture, is defined as landless cultivation. The advantage of hydroponic systems is that it does not require a large area, so it is suitable to be used for narrow land. There are several types of hydroponic systems one of which is the NFT (Nutrient Film Technique) hydroponics system. NFT is the type of hydroponic system in which plants are placed in a sloping irrigation channel with a film of nutrient solution flowing over the roots. The nutrient solution is collected in a reservoir and is continually pumped back to the start of the channel (Park and Muray, 2011). 
Nowadays, vegetables are in great demand by the public. The high public interest in vegetables along with the increasing population. It is estimated that Indonesia's population in the next five years will reach 276 million with an average population growth of 1.36\% (BPS, 2017). Based on data from the Central Statistics Agency (2017), pak choi (Brassica rapa L.) production in Indonesia from 2013 to 2017 was in a consecutive of 635.728 tons, 602.478 tons, 600.200 tons, 601.204 tons and 627.598 tons. The data shows that pak choi production in Indonesia has always fluctuated. The increase in production from 2015 to 2017 is still insufficient to meet pak choi's demand of 635.728 tons in 2013.

Pak choi's low productivity in Indonesia is due to the agricultural land productivity which are limited, it is necessary to improve the pak choi cultivation system and increase the quality and quantity of pak choi's products. Hydroponics is an alternative cultivation technique that can be developed for vegetable planting. Pak choi is a short-lived plant and has a high nutrient content. Pak choi cultivation techniques and have broader market potential along with increasing community needs for high-quality vegetables and is one of the most popular vegetable crops in the community.

In the cultivation of hydroponic systems, the main component that becomes an important factor is nutrient solution. Nutritional solutions to hydroponics must be done accurately, so that the final concentration is desired. Currently 17 elements are considered essential for most plants, these are nitrogen, phosphorus, potassium, calcium, magnesium, sulphur, iron, copper, zinc, manganese, molybdenum, boron, chlorine, nickel, carbon, hydrogen, and oxygen, (Salisbury and Ross, 1994). With the exception of carbon (C) and oxygen (O), which are supplied from the atmosphere, the essential elements are obtained from the growth medium. Other elements such as selenium, silicon, vanadium, cobalt, aluminum, iodine, and sodium, among others, are considered beneficial because some of them can stimulate the growth, or may replace essential nutrients in a less specific role, or can compensate the toxic effects of other elements (TrejoTéllez et al., 2007).

There are two important factors in making nutrient solutions in the hydroponic system, were the composition and the concentration of solution. At doses that are too low the plant will have nutrient deficiencies whereas in doses that are too high the plant will be poisoned. One of the efforts that can be done is to make efficient use of inorganic fertilizers on hydroponic systems with the application of bio-fertilizers. Li and Zhang, (2000) state that among the factors modifying yielding and the nutritional status of plants, at the same time, their nutritive and biological value, are as follows, among others: application of fertilizers and also the application of useful microorganisms. Particularly interesting is the pressure from a part of consumers to apply microbes and to reduce the quantity of chemical components used in foodstuffs (Amjadi and Hussain, 2005). Among the group of microbes that could be used in hydroponic cultivation are the following, among others: nitrogen-fixing bacteria Azospirillum and Azotobacter (Abdelaziz and Pokluda, 2009).

It has been confirmed that microbes possess the ability to fix atmospheric nitrogen and also to produce growth substances, which enables better development and better branching of the root system, and by so doing, helps in the rationalization of water management and also in the uptake 
of mineral salts by plants (Król, 2006). The symbiosis of plants with microbes are conditional on different chemical and physical factors (Bol et al., 2003).

Bio-fertilizers are fertilizers derived from living microorganisms that can convert nutrients from forms that cannot be used to become available forms for plants. The bio-fertilizer consortium is an inocula made from more than one microbe (Azotobacter sp., Azospirillum sp., endophytic bacteria and phosphate solubilizing bacteria) containing $\mathrm{N}$ fixing bacteria. One of the $\mathrm{N}$ fixing bacteria is Azotobacter sp. which can convert nitrogen in the atmosphere to ammonia through a nitrogen binding process where the ammonia produced is converted into a protein needed by plants (Hamastuti et al., 2012). The use of $\mathrm{N}$-fixing bacteria has the potential to reduce the need for synthetic $\mathrm{N}$ fertilizer, increase farm production and income with cheaper inputs. Based on the description above, it is necessary to conduct a study of the effect of combination of bio-fertilizer and inorganic fertilizer to decrease inorganic fertilizer need and increase on chlorophyll content, $\mathrm{pH}$, and the number of leaves pak choi yield in the NFT hydroponic systems.

\section{MATERIALS AND METHODS}

The research was conducted from November 2018 to April 2019. The place of research was conducted at the Laboratory of Soil Biology, Faculty of Agriculture, Universitas Padjadjaran for pak choi NFT hydroponic systems planting that is indoors and using LED lights lighting assistance. The lighting used blue light 500-600 nm and red light 600-700 nm. The light is turned on for 12 hours which is adjusted to the time of day and 12 hours the lights are turned off according to night time.

The materials used in the research are pak choi seeds of Flaminggo variety, inorganic fertilizers for hydroponic leaf vegetable plants consisting of solutions A and B (basic inorganic fertilizers) and $\mathrm{C}$ solutions (nitrogen fertilizer $\mathrm{NH}_{4} \mathrm{NO}_{3}$ ), bio-fertilizers consortium of Soil Biology Laboratory products (Azotobacter sp., Azospirillum sp., Endophytic bacteria N-fixer, and phosphate solubilizing bacteria).

The research method was carried out experimentally consisting of four combinations of the treatment dose of $\mathrm{NH}_{4} \mathrm{NO}_{3}$ (Ammonium Nitrate) as Nitrogen Fertilizer (NF) with Bio-fertilizer (BF). The combination of the treatment was dissolved in Basic Inorganic Fertilizer (BIF) in $15 \mathrm{~L}$ distilled water for each treatment, each treatment was repeated six times for different time periods with the following treatment.

$\mathrm{A}=\mathrm{BIF}+150 \mathrm{~mL} \mathrm{NF}+0 \mathrm{~mL} \mathrm{BF}$

$\mathrm{B}=\mathrm{BIF}+100 \mathrm{~mL} \mathrm{NF}+75 \mathrm{~mL} \mathrm{BF}$

$\mathrm{C}=\mathrm{BIF}+50 \mathrm{~mL} \mathrm{NF}+125 \mathrm{~mL} \mathrm{BF}$

$\mathrm{D}=\mathrm{BIF}+25 \mathrm{~mL} \mathrm{NF}+150 \mathrm{~mL} \mathrm{BF}$

Nutrition is made by making a primer solution, solution A consists of $\mathrm{Ca}\left(\mathrm{NO}_{3}\right)_{2} 200 \mathrm{mg}$, $\mathrm{KNO}_{3} 70 \mathrm{mg}$, Fe EDTA $8 \mathrm{mg}$. Solution B consisted of $70 \mathrm{mg} \mathrm{KH}{ }_{2} \mathrm{PO}_{4}, \mathrm{MgSO}_{4} .7 \mathrm{H}_{2} \mathrm{O} 160 \mathrm{mg}$, 
$\mathrm{MnSO}_{4} 0.4 \mathrm{mg}, \mathrm{H}_{3} \mathrm{BO}_{4} 0.4 \mathrm{mg}, \mathrm{CuSO}_{4} 0.2 \mathrm{mg}, \mathrm{ZnSO}_{4} 0.2 \mathrm{mg}, \mathrm{Na}_{2} \mathrm{MoO}_{4} 0.04 \mathrm{mg}$. Solution $\mathrm{C}$ consists of $\mathrm{NH}_{4} \mathrm{NO}_{3} 70 \mathrm{mg}$. Each solution was dissolved in $2 \mathrm{~L}$ distilled water.

The experiment was arranged in Randomized Block Design (RBD) to saw the effect of treatment with six replications, the data were analyzed using Fisher's Test $(p=0.05)$. If there is a significant effect, it was carried out Duncan's New Multiple Range Test ( $\mathrm{p}=0.05)$.

\section{RESULTS AND DISCUSSION}

\section{Chlorophyll Content}

Observation of leaf chlorophyll content was carried out when harvesting pakcoy plants four weeks after planting. Based on Table 1, shows that the treatment with a combination of inorganic fertilizers with bio-fertilizers did not have a significant effect on the leaf chlorophyll content.

Chlorophyll content correlates with plant N content. In line with the opinion of Sampson et al., (2003) which states that the high and low chlorophyll content is directly proportional to the availability of nitrogen elements and plays an important role in the process of photosynthesis. The higher amount of nitrogen available by plants make a higher chlorophyll content in the leaves so that the photosynthesis takes place quickly. Increased plant nitrogen triggered by beneficial bacteria in bio-fertilizers added to the NFT system hydroponic nutrient solution. Benefit bacteria that colonize plant roots and enhance plant growth by any mechanism are referred to as plant growth-promoting rhizobacteria (PGPR).

Table 1. Effect of Combination of Inorganic Fertilizer and Bio-fertilizer on Pak choi Chlorophyll Leaves

\begin{tabular}{ll}
\hline Treatment & $\begin{array}{l}\text { Chlorophyll } \\
\text { Content } \\
(\mathrm{CCI})\end{array}$ \\
\hline $\mathrm{A}=150 \mathrm{~mL}$ Ammonium Nitrate (control) & 13.83 \\
$\mathrm{~B}=100 \mathrm{~mL}$ Ammonium Nitrate $+75 \mathrm{~mL}$ Bio-fertilizer & 17.75 \\
$\mathrm{C}=50 \mathrm{~mL}$ Ammonium Nitrate $+125 \mathrm{~mL}$ Bio-fertilizer & 19.08 \\
$\mathrm{D}=25 \mathrm{~mL}$ Ammonium Nitrate $+150 \mathrm{~mL}$ Bio-fertilizer & 19.13
\end{tabular}

Note : The treatments do not have numerics followed by the letters were non significant on 95 $\%$

Duncan's New Multiple Range Test.

PGPR have been applied on various crops to enhance growth, seed emergence, crop yield, and disease control, and some have been commercialized (Dey et al., 2004). PGPR can promote plant growth indirectly or directly. Indirect plant growth promotion is mediated by antibiotics or 
siderophores produced by PGPR that decrease or prevent the deleterious effects of plant pathogenic microorganisms (Sivan and Chet, 1992). Direct plant growth-promoting factors include various phytohormones (Xie et al., 1996), solubilization of soil phosphorus and iron (De Freitas et al., 1997), N fixation (Christiansen and Weneger, 1992), increases in nitrate uptake (Sophie et al., 2006).

In treatment $\mathrm{D}(25 \mathrm{~mL}$ of ammonium nitrate $+150 \mathrm{~mL}$ of bio-fertilizer) showed the role of bio-fertilizers in increasing chlorophyll content of leaves even though inorganic fertilizers were given in low doses, thus obtaining a higher chlorophyll content compared to other treatments and more efficient because they were able to reduce use inorganic fertilizer of $83.33 \%$. This is thought to be $\mathrm{N}$-fixing bacteria contained in bio-fertilizers perform free $\mathrm{N}$-fixing activity in the air which is able to increase the N content. Supported by research by Rueda et al. (2016) which states that the provision of bio-fertilizers containing PGPR Azotobacter sp. which combined with Nitrogen $100 \mathrm{ppm}$ can increase the amount of leaf chlorophyll content by 53.37 Chlorophyll Content Index (CCI) compared to the control on hydroponic strawberry plants.

Berkelmann et al. (1994) state that microorganisms multiply rapidly on roots and in nutrient solutions. Large populations of heterotrophic bacteria $\left(10^{5}-10^{6} \mathrm{cfu} \mathrm{mL}^{-1}\right)$ developed in the circulating nutrient solutions $20 \mathrm{~h}$ after planting tomatoes. The number of bacteria on young tomato roots can be as high as $10^{10} \mathrm{cfu}^{-1}$ of fresh roots (Waechter-Kristensen et al., 1994). However, there are differences between microbial communities colonizing roots and nutrient solutions; more fungi and bacteria were detected on roots than in nutrient solutions.

\section{pH Nutrient Solution}

The $\mathrm{pH}$ is another parameter that plays an important role in hydroponic systems. The $\mathrm{pH}$ value is an indicator that can determine fertility because the availability of nutrients for plants is closely related to the $\mathrm{pH}$ value of nutrients. The $\mathrm{pH}$ is a parameter that measures the acidity or alkalinity of a solution. The $\mathrm{pH}$ effect on the availability of nutrients to plants. Changing the $\mathrm{pH}$ of a nutrient solution affects its elemental speciation, composition, and bioavailability. The term "speciation" indicates the distribution of elements among their various physical and chemical forms like: soluble complexes, free ions, chelates, ion pairs, solid and gaseous phases and different oxidation states (De Rijck and Schrevens, 1998). Based on Table 2. shows that the treatment with a combination of bio-fertilizers and inorganic fertilizers did not have a significant effect on the $\mathrm{pH}$ of nutrient solutions.

From the results of the observation, the $\mathrm{pH}$ value in all treatments ranged from 6.6 to 6.7 which is still within the tolerance range of the pak choi plant $\mathrm{pH}$ of $6.5-7.0$. In that range the bast solubility of macro and micro nutrients. If the $\mathrm{pH}$ is less than 6.5 or more than $\mathrm{pH} 7.0$ causes some elements to settle so that it cannot be absorbed by the roots and consequently the plant experiences a related element deficient. If the $\mathrm{pH}$ range too high for vegetables, the nutrients in nutrient solutions are difficult to dissolve and not available to plants. Marschner (1995) said that an important feature of the nutrient solutions is that they must contain the ions in solution and in chemical forms that can be absorbed by plants, so in systems of hydroponic the plant productivity is closely related with to the $\mathrm{pH}$ regulation and nutrient uptake.

If there is an increase in $\mathrm{pH}$ value then an acid solution is added to the water reservoir, whereas if there is a decrease in $\mathrm{pH}$ value then $\mathrm{NaOH}$ solution is added. The concentration of liquid 
organic fertilizer dissolved in a measured water must be appropriate to the needs of the plant. In lower concentrations, the effectiveness of fertilizers is reduced, whereas if excessive, the plants wilt or even die. This is in line with the research of Wijayani and Widodo (2005) which states that concentrated solutions cannot be absorbed maximally by plant roots because the cell osmotic pressure becomes smaller than the osmotic pressure outside the cell so that the possibility of backflow of liquid plant cells or plasmolysis.

Table 2. Effect of Combination of Inorganic and Bio-fertilizers on pH media

\begin{tabular}{|ll|}
\hline Treatment & $\mathrm{pH}$ \\
\hline $\mathrm{A}=150 \mathrm{~mL}$ Ammonium Nitrate (control) & 6.72 \\
$\mathrm{~B}=100 \mathrm{~mL}$ Ammonium Nitrate $+75 \mathrm{~mL}$ Bio-fertilizer & 6.66 \\
$\mathrm{C}=50 \mathrm{~mL}$ Ammonium Nitrate $+125 \mathrm{~mL}$ Bio-fertilizer & 6.63 \\
$\mathrm{D}=25 \mathrm{~mL}$ Ammonium Nitrate $+150 \mathrm{~mL}$ Bio-fertilizer & 6.67
\end{tabular}

Note : The treatments do not have numerics followed by the letters were non significant on $95 \%$ Duncan's New Multiple Range Test.

Treatment $\mathrm{B}$ to $\mathrm{D}$ produces a relatively lower $\mathrm{pH}$ value compared to treatment $\mathrm{A}$ (control). This is because the presence of bio-fertilizers contained makes the $\mathrm{pH}$ value decrease. In line with the research of Tanjung et al. (2017) which states that the addition of bio-fertilizers to nutrient solutions causes an increase and decrease in $\mathrm{pH}$ due to the activity of microorganisms that break down the components in solution every day. Many bacteria change the $\mathrm{pH}$ of their medium. Most common is the secretion/excretion of organic acids such as lactic acid, by the well-known lactic acid, or acetic acid bacteria, or the secretion of ammonia and other basic compounds. Zhang et al. (2016) said that extracellular $\mathrm{pH}$ has a strong effect on cell metabolism and growth. Precisely detecting extracellular $\mathrm{pH}$ with high throughout is critical for cell metabolism research. Beside that Widyati (2013) had explaned Microbial respiration and plant roots will release $\mathrm{CO}_{2}$ which can increase the concentration of carbonic acid or bicarbonate so that it can reduce $\mathrm{pH}$. Their states vigour that $\mathrm{pH}$ values in liquid media are influenced by several factors including biological activities.

Tyson et al. (2007) in a study to determine the nitrification rate response in a perlite trickling biofilter (root growth medium) exposed to hydroponic nutrient solution, varying $\mathrm{NO}_{3}{ }^{-}$ concentrations in $\mathrm{pH} 6.5$ and 8.5, founded that nitrification was significantly impacted by water $\mathrm{pH}$. The increased ammonia oxidation rate (1.75) compared to the rate of nitrite oxidation (1.3) at $\mathrm{pH} 8.5$ resulted in accumulation of $\mathrm{NO}_{2}^{-}$to levels near those harmful to plants (observed peak of $4.2 \mathrm{mg} \mathrm{L}^{-1} \mathrm{NO}_{2}^{-}$). The potential for increased levels of un-ionized ammonia, which reduced plant nutrient uptake from micronutrient precipitation, associated with $\mathrm{pH} 8.5$ are additional problems. 
Vol. 4, No. 04; 2019

ISSN: $2456-8643$

\section{Number of Pak choi Leaves}

The number of leaves is a component that shows the results of pak choi plants. Observation of the number of leaves is carried out every week starting from 1 WAP (Week after Planting) to 4 WAP. Observation of the number of leaves is done by counting adult leaves or leaves that are wide open. Based on Table 3. shows that the treatment with a combination of inorganic fertilizers and bio-fertilizers had a significant effect on increasing the number of leaves of the pak choi plants.

Table 3. Effect of Combination of Inorganic Fertilizers and Bio-fertilizers on Number of Leaves

\begin{tabular}{|lcc|}
\hline Treatment & $\begin{array}{l}\text { Number } \\
\text { (strand) }\end{array}$ & of Lea \\
\hline $\mathrm{A}=150 \mathrm{~mL}$ Ammonium Nitrate (control) & $5.90 \mathrm{a}$ \\
$\mathrm{B}=100 \mathrm{~mL}$ Ammonium Nitrate $+75 \mathrm{~mL}$ Bio-fertilizer & $7.22 \mathrm{~b}$ \\
$\mathrm{C}=50 \mathrm{~mL}$ Ammonium Nitrate $+125 \mathrm{~mL}$ Bio-fertilizer & $7.74 \mathrm{c}$ \\
D = $25 \mathrm{~mL}$ Ammonium Nitrate $+150 \mathrm{~mL}$ Bio-fertilizer & $8.04 \mathrm{~d}$
\end{tabular}

Note: Numerics followed by the same letters were non significant on $95 \%$ Duncan's New Multiple Range Test.

$\mathrm{D}$ treatment $(25 \mathrm{~mL}$ of ammonium nitrate $+150 \mathrm{~mL}$ bio-fertilizer) was significantly different from treatment A (control) with the number of leaves as much as 8.04 strands. This is presumably because nutrient requirements for pak choi in treatment $\mathrm{D}$ have been fulfilled. In line with the opinion of Sembiring and Moch (2018) which states that plants can grow well if the nutrients are given in a balanced amount and according to the needs of plants. One of the important nutrients needed in leaf formation is Nitrogen.

The microbial content contained in the consortium of bio-fertilizers, especially Azotobacter sp. able to fixing Nitrogen from the air through the activity of $\mathrm{N}$-fixing bacteria and stimulate the compilation process through the secretion of fitohormones. Jumin (2002) states that $\mathrm{N}$ functions include increasing vegetative growth, especially the number of leaves. This agrees with the research of Vivonda et al. (2016) which states that $\mathrm{N}$ elements play a role in leaf formation, with the availability of $\mathrm{N}$ elements, photosynthesis will increase and photosynthate can be used by plants for leaf formation.

Based on these observations, the higher dose of bio-fertilizer given to pak choi hydroponic plants have increasing the higher number of leaves. This shows that increasing doses of biofertilizers, especially those containing $\mathrm{N}$-fixing microbes, can increase the amount of nutrient availability for plants so that it can increase the growth of leaf numbers.

Kleiber et al. (2013) stated that the study found a positive effect of Effective Microbes with the application of nutrient solution on the production of the highest quantity of leaves per plant. 
Also, the significant influence of nutrient solution composition on plant biological parameters was confirmed. An increase nutrient concentration in hydroponic cultivation, are positively influenced the total number lettuce's (Lactuca sativa L.) leaves.

Earlier studies (Myczkowski et al. 1990) show in addition had it that a higher quantity of fertilizer applied in NFT significantly influences the nitrate status of lettuce leaves cultivated, compared to illumination and regulatory growth. Valverde et al. (2009) has been confirmed that in hydroponic lettuce cultivation systems harvested plants are characterized by good quality shown, amongst others, due to lower amounts of nitrate.

\section{CONCLUSIONS}

Based on the results of the research conducted conclusions can be taken as follows:

1. Inorganic fertilizers combined with bio-fertilizers in hydroponic systems have a significant effect on increasing the number of leaves. However, it did not significantly affect the increase in chlorophyll content and $\mathrm{pH}$.

2. The combination of a dose of $25 \mathrm{~mL}$ ammonium nitrate inorganic fertilizer with $150 \mathrm{~mL}$ of bio-fertilizer was the best treatment dose to increase the number of leaves pak choi.

\section{ACKNOWLEDGEMENTS}

Research supported by Priority Research of DRPMI Universitas Padjadjaran as part of the activities of Soil Biology Laboratory at Soil Science Department, Universitas Padjadjaran. West Java, Indonesia.

\section{REFERENCES}

Abdelaziz M.E and Pokluda R, 2009. Response of cucumbers grown on two substrates in an open soilless system to inoculation with microorganisms. Acta Hort. 819:157-164.

Amjadi K and Hussain, K. 2005. Integrating food hygiene into quantity food production systems. Nutrition \& Food Science, 35 (3): 169-183. http://dx.doi.org/ 10.1108/00346650510594921

Berkelmann B., Wohanka W., and Wolf G.A. 1994. Characterization of the bacterial flora in circulating nutrient solutions of a hydroponic system with rockwool, Acta Hort. 361, 372-381.

Bol R., Kandeler E., Amelung A., Glaser B., Marx M.C., Preedy N., and Lorenz K. 2003. Shortterm effects of dairy slurry amendment on carbon sequestration and enzyme activities in a temperature grassland. Soil Biol. Biochem. 35: 1411-1421.

BPS. Central Bureau of Statistics and Directorate General of Horticulture. 2017. Pakcoy's Productivity in Indonesia, 2013-2017. Central Bureau of Statistics and Directorate General of Horticulture

Christiansen-Weneger C. 1992. N2-fixation by ammonium-excreting Azospirillum brasilense in auxin-induced tumours of wheat (Triticum aestivum L.). Biol Fertil Soils 12: 85-100 
De Freitas JR, Banerjee MR, and Germida JJ. 1997. Phosphate solubilizing rhizobacteria enhance the growth and yield but no phosphorus uptake of canola (Brassica napus L.). Biol Fertil Soils 24: 358-364

De Rijck G. and Schrevens E. 1998. Cationic speciation in nutrient solutions as a function of $\mathrm{pH}$. Journal of Plant Nutrition, Vol.21, No.5 (May 1998), pp. 861-870, ISSN. 0190-4167

Dey R, Pal KK, Bhatt DM, Chauhan SM. 2004. Growth promotion and yield enhancement of peanut (Arachis hypogaea L.) by application of plant growth-promoting rhizobacteria. Microbiol Res 159: 371-394

Hamastuti, H., Dwi, E., Juliastuti, S., and Hendrianie, N. 2012. The role of Azotobacter chroococcum, Pseudomonas fluorescens and Aspergillus niger microorganisms in making compost sludge waste in the milk processing industry. Jurnal Teknik Pomits, 1(1), 1-5.

Jumin H. B. 2002. Agronomy. PT. Raja Grafindo Persada. Jakarta. Indonesia

Kleiber T, Starzyk J, and Bosiacki M. 2013. Effect of nutrient solution, effective microorganisms (EM-a), and assimilation illumination of plants on the induction of the growth of lettuce (Lactuca sativa L.) in hydroponic cultivation. Acta Agrobotanica. Vol. 66 (1), 2013: 27-38.

Król, J.M. 2006. Azospirillum-asociacing bacteria fixing atmospheric nitrogen. Institute of Cult., Fertiliz. Soil Sci. 14-15.

Li Z. and Zhang H. 2000. Application of microbial fertilizers in sustainable agriculture. J. Crop Production 3,1 (5): 337-347. http://dx.doi.org/10.1300/J144v03n01_28

Marschner, H. 1995. Mineral Nutrition of Higher Plants, Academic Press, ISBN 0-12-473542-8, New York, U. S. A.

Myczkowski J., Rozek S., Sady W., and Wojtaszek T. 1990. The effect of some factors on the content of nitrate and nitrite in lettuce leaves grown with the nutrient Film technique. II. Effect of light and growth regulators in conditions of NPK fertilization discontinued before harvest. Folia Hort. II/1: 7-16.

Park S. and Muray C. 2011. Leafy Asian Vegetables and their Nutrition in Hydroponics. Published by Industry \& Investment NSW. ISBN 9781742560779.

Rueda, D., G. Valencia, N. Soria, B. B. Rueda. B. Manjunatha, R. R. Kundapur and M. Selvanayagam. 2016. Effect of Azospirillum spp. and Azotobacter spp. on the growth and a yield of strawberry (Fragaria vesca) in hydroponic system under diferrent nitrogen levels. Journal of Applied Pharmaceutical Science, 6(1): 48 - 54.

Salisbury, F. B. and Ross, C. W. 1994. Plant Physiology. Wadsworth Publishing Company, ISBN 0-534-15162-0, California, U.S.A. 
Sampson, P.H., Zarco, T.P., Mohammed, G.H., Miller, J.R. and Noland, T. 2003. Hyper spectral remote sensing of forest condition: estimating chlorophyll content in tolerant hardwoods. Forest Science 49. (3): $381-391$.

Sembiring, G. M. dan Moch. Dawam M. 2018. Effect of nutrient composition and leaf fertilizer on the growth and yield of pak choi plants (Brassica rapa L. Var. Chinensis) floating raft hydroponic systems. Jurnal Produksi Tanaman, Vol. 5, No. 5. (In Indonesian)

Sivan A, and Chet I. 1992. Microbial control of plant diseases. In R Mitchell, ed, Environmental Microbiology. Willey-Liss, New York, pp 335-354.

Sophie M., Guilhem D., Marie le L., Timothy JT, Jean-Claude CM, and Bruno T. 2006. Nitratedependent control of root architecture and $\mathrm{N}$ nutrition are altered by a plant growth-promoting Phyllobacterium sp. Planta 223: 591-603

Tyson, R. V., Simonne, E. H., Davis, M., Lamb, E.M., White, J.M. and Treadwell, D.D. 2007. Effect of nutrient solution, nitrate-nitrogen concentration, and $\mathrm{pH}$ on nitrification rate in perlite medium. Journal of Plant Nutrition, Vol.30, No.6, pp. 901-913, ISSN 0190-4167.

Valverde K., Chang M., and Rodríguez-Delfín A. 2009. Effect of the light quality on the nitrate reductase activity in lettuce plants grown in NFT. Acta Hort. 843: 89-96.

Vivonda, T., Armaini and Sri Yoseva. 2016. Optimalitation the growth and production of pakchoy (Brassicca rapa L) crop through the multiple dose of bokashi fertilizer. JOM Faperta, The Faculty of Agricultute, Riau Vol. 3 No.2.

Waechter-Kristensen B., Gertsson U.E., and Sundin P. 1994. Prospects for microbial stabilization in the hydroponic culture of tomato using circulating nutrient solution, Acta Hort. 361, 382-387.

Widyati, E. 2013. Understanding on Plants-Microbes Interaction. Jurnal Tekno Hutan Tanaman. 6(1): 13-20.

Wijayani, A., and Widodo, W. 2005. Efforts to improve the quality of some tomato varieties with the hydroponic cultivation system. Ilmu Pertanian 12(1): 77-83.

Xie, H., Pasternak, J.J. and Glick, B.R. 1996. Isolation and characterization of mutants of the plant growth-promoting rhizobacterium Pseudomonas putida GR12-2 that over produce indol acetic acid. Current Microbiology 32, 67-71.

Zhang L, Su F, Kong X, Lee F, Day K, Gao W, Vecera M. E., Sohr J. M., Buizer S., Tian Y., and Meldrum. D.R. 2016. Ratio metric fluorescent $\mathrm{pH}$-sensitive polymers for highthroughput monitoring of extracellular pH. RSC Advances Journal. Issue 52, 2016. 